International Journal of Social Science and Economic Research

ISSN: 2455-8834

Volume:05, Issue:10 "October 2020"

\title{
THE ASSESSMENT OF THE NEXUS BETWEEN OFFICIAL DEVELOPMENT ASSISTANCE AND GDP: AN EMPIRICAL STUDY ON BANGLADESH
}

\author{
S.M.Nasir Uddin ${ }^{1}$, Afif Bin Mustakim², Md.Deloar Hossain ${ }^{3}$, Anika Binte Shafiq ${ }^{4}$ \\ ${ }^{1}$ Lecturer, Department of Economics, Bangabandhu Sheikh Mujibur Rahman Science and Technology \\ University, Gopalganj-8100, Bangladesh. \\ ${ }^{2}$ Lecturer, Department of Business Administration, Bangladesh Army University of Science and \\ Technology,Saidpur-5310, Nilphamari, Bangladesh. \\ ${ }^{3}$ M.Sc., Department of Economics, Jahangirnagar University, Savar, Dhaka-1342, Bangladesh. \\ ${ }^{4}$ M.Sc., Department of Economics, Jahangirnagar University, Savar, Dhaka-1342, Bangladesh.
}

DOI: 10.46609/IJSSER.2020.v05i10.013 URL: https://doi.org/10.46609/IJSSER.2020.v05i10.013

\begin{abstract}
The paper provides the assessment of the nexus between official development assistance (ODA) and gross domestic product (GDP) in Bangladesh. The official development assistance is termed as foreign aid supplied by the advanced countries to developing and less developed countries for the upgradation of their livelihood and not for the progress of military purposes. GDP depicts a quick scenario of a country by assessing the size of the economy over a period of time. Time series yearly data from 1971 to 2018 has been used for the analysis. After ADF analysis for the stationarity of data ARDL bound test has been used for determining the short-run along with long-run association between the variables. The evidence has been found that in the long-run ODA and GDP are cointegrated. The ECM model exposes the equilibrium that converges to steady state at $65 \%$ annually by analyzing ECM. The Granger Causality test in the short run OLS model indicates a unidirectional causality between ODA and GDP that means ODA causes GDP. Again in the long run OLS model there also have unidirectional causality between GDP and ODA and it indicates that GDP cause ODA and identified as GDP and ODA are not separate variables. A set of robustness test affirm the accuracy of the analysis. Lot of study is needed in this aspect to get more empirical information about the effectiveness of the official development assistance and economic overview of this country.
\end{abstract}

Key words: Official Development Assistance (ODA), Gross Domestic Product (GDP), Augment Dicky-Fuller (ADF) test, Auto Regressive Distributed Lag (ARDL) bound test, Cointegration, OLS, ECM, Granger Causality. 
International Journal of Social Science and Economic Research

ISSN: 2455-8834

Volume:05, Issue:10 "October 2020"

\section{Introduction}

At the age of globalization, the interdependence among the country has been increased. Exchange of goods and services, technology are done by the term open trade worldly. Developed countries have been trying to expand their hand to the most vulnerable country for development through the following word official development assistance (ODA). It is an indispensable factor to stimulate economic growth in developing countries. It is the financing process through which a developed country's government allocates loan, grants or capital out flow to developing country. ODA is compiled with movement of credit in which one quarter is concessional. Aid flows for newly developing countries from the donor country is finally anticipated to help the donee countries to acquire durable long term development actually in the sector of capital augmentation, sustainable economic enlargement, deficit reduction, poorness alleviation and controlling fatality rate (Ugwuanyi et al., 2017).

Basically ODA is not for the upgradation of military purposes .Bangladesh is also a developing country facing a large amount of budget deficit that reflects the importance of ODA for GDP.

Ahmed (2017) found the way that accumulates more tax revenue by controlling internal sources may perform against budget deficit. Beside this controversy ODA have some influences on economic growth that is assessing in this work.

GDP, one of the leading indicator, measures the health of the economy. GDP is measured by calculating the final worth of goods and services that is made within the territory of a country in a particular time like annually, half yearly and quarterly.

Simon Kuznets, an economist at the National Bureau of Economic Research, was identified the term GDP in1937 through a notice to U.S. Congress in reaction to Great depression. GNP was the best method of measurement at that time. Bretton Woods conference was executed in 1944, after that GDP was accepted extensively as the ideal measurement of national economies. Until 1991 USA used GNP, after that it changed to GDP. (Investopedia, 2020).

\section{Official Development Assistance scenario in Bangladesh}

Bangladesh had received 4.91 (\% of gross capital formation) of net ODA in 2017 . The maximum value was 89.63 in 1975 among the last 46 years, while the lowest value in1971 was 2.13 .

In other measurement Bangladesh received 1.44 of net ODA (\% of GNI) in as of 2017. In which the highest and the lowest value was 8.16 and 1.07 consecutively. 
International Journal of Social Science and Economic Research

ISSN: 2455-8834

Volume:05, Issue:10 "October 2020"

We can also see the net ODA received (percentage of imports of goods, services and primary income) was 6.31 at 2017 in Bangladesh. The highest and the lowest value over the past 41 years was 62.12 and 3.78 .

In the measurement of $\%$ of central government expense net ODA received by Bangladesh was 12.01 in 2016. The maximum value in the past 15 years was 29.65 in 2003, as the minimum value was 11.80 in 2011.

Source: DAC of the OECD, Geographical Distribution of Financial Flows to Developing Countries, Development Co-operation Report, and International Development Statistics database.

In 2018 the net official development assistance received 3040219971(Current USD) which was 3.55 (percentage of gross capital formation) 1.06 (\% of GNI) and 4.47 (\% of imports of goods, services and primary income). (WDI, 2020).

\section{GDP scenario of Bangladesh}

After independence the economic situation of Bangladesh was vulnerable. Lot of hardship and struggle had been faced by this country to move on after 9 months of sanguinary battle. The NGDP of Bangladesh in June 2019 was 302.2 billion USD compared with the previous fiscal year was 207.0 billion USD. As GDP is measured annually the highest NGDP was calculated in June 2019 whereas the lowest NGDP was recorded in June 1960 amount of 4.6 billion USD. GDP per capita of Bangladesh has reached 1828 USD in June 2019 with gross savings rate has been calculated at $29.5 \%$.(CEIC, 2020).

Bangladesh economy is up growing gradually .Bangladesh is the 39th substantial economy in the world in the measurement of NGDP, and 30th biggest by PPP. The economy of Bangladesh is distinguished as the rising market middle income economy in the world. With a high RGDP annual growth rate of $7.3 \%$ in June 2019 Bangladesh was considered the world's seventh fastest growing economy (Wikipedia, 2020).

Ahamad et al. (2019) have identified that since 1971 Bangladesh had been receiving ODA. That is basically given for filling internal and external deficits, welfare for the people, financing infrastructural development, eliminating poverty, relive the economy from the losses from natural disasters etc.

\section{Theoretical Framework}

GDP is the yardstick that indicates how the country is going on, what is the position of that country among the world, how the living standard of that country, how much their earnings, how much integrated they are with the rest of the world etc. There have lot of factors that influence 


\section{International Journal of Social Science and Economic Research}

ISSN: $2455-8834$

Volume:05, Issue:10 "October 2020"

the economic growth of a country. Some factors like FDI, money supply, population, investment, export, and import may lead to a change in economic indicators of a country. ODA is one of them could influence a country's GDP.

Ahamad et al. (2019) have measured the effect of official development aid on economic expansion in Bangladesh. In the short run as well as long run, official aid showed a remarkable positive impression on economic growth that ensured a positive aid growth relationship in Bangladesh. They found in short run a $10 \%$ rise in per capita aid induce to $0.54 \%$ increment in per capita GNI and in the long run a $1 \%$ increment in per capita aid induce to $0.27 \%$ expand in per capita GNI.

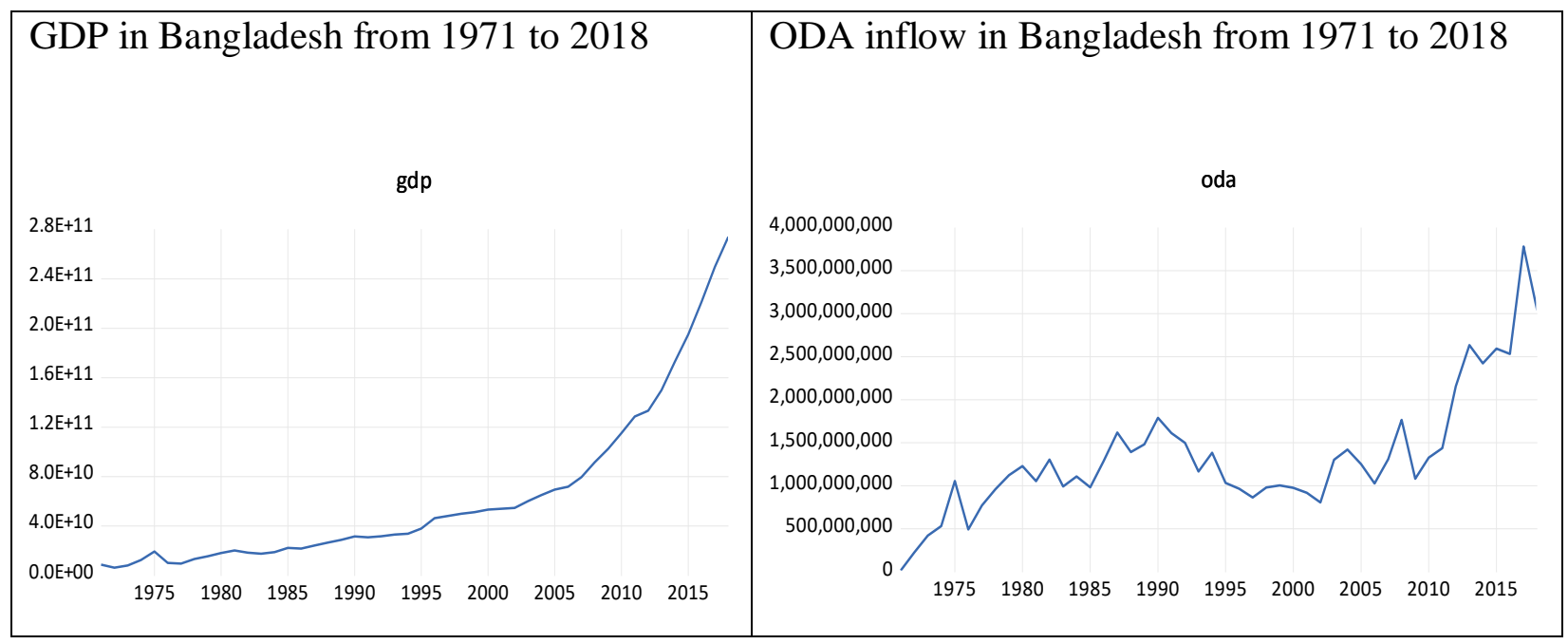

Figure 1: GDP and ODA inflow in Bangladesh

In the fig 1: shows GDP and ODA inflows in Bangladesh from the period of 1971 to 2018. There have not a drastically change in ODA flow until 2010.The ODA inflow begun to increase after 2010 with a long jump to 2015. After 2016 made a boom and changed a big inflow in Bangladesh. In 2018 it came to a fall down as shown in the figure 1.

In fig 1: showed that the time trend of GDP in Bangladesh has been experienced a steady and positive growth from 1976 to 2000.After 2000 to 2018 GDP raised at higher increasing rate. The growth rate of GDP in 2018 was $8 \%$ and in 2017 it was 7.6\%. In1971the growth rate of GDP was $-5.5 \%$ and the lowest minimum growth rate was $-13.97 \%$ in 1972 .

Refaei and Sameti (2015) took it out into the view that the foreign assistance and economic enhancement have an ordinary positive relationship, mathematically effective, and not trivial in type. One unit increment of foreign aid led to a $0.017 \%$ rise in economic prosperity. Therefor they claimed that foreign aid is more effective than internal resources and other credit inflows. 


\section{International Journal of Social Science and Economic Research}

ISSN: $2455-8834$

Volume:05, Issue:10 "October 2020"

\section{Literature Review}

A lot of works have been conducted for the purpose of identifying the nexus between official development assistance and gross domestic product of different countries over the world. Basically all of the studies were completed through different econometric methodology. But still now it is a question of whether official development assistance encourages or discourages economic growth. Ahamad et al. (2019) have identified that in the long run and in the short run per capita foreign assistance affects per capita GNI positively. Razak et al. (2019) exerted that ODA has had a negative influence on the economy in Togo moreover the influence was statistically not significant. The Granger causality result depicted that there was not any causal relationship existence in between ODA and economic growth in Togo.

Mustafa et al. (2019) have uncovered that a long run affinity between variables were existed. Actually in Sudan, the cash inflow by the term of official development assistance (ODA) has positive and long run significant effect on economic growth. Another work revealed that ODA affect similarly as like as Mustafa et al. (2019) on economic growth. In nut shell the contribution of (ODA) is considerable to economic enrichment in less developed and gradually economic increasing countries. (Dan and Binh, 2019).

So it is clear that the influence of ODA on GDP is a controversial case for several countries. We are going to assess the relatedness of ODA and GDP in Bangladesh. We reconsider a lot of study from several scholars that may help us to think about the main theme of ODA and GDP relationship.

Tien (2019) revealed that for underdeveloped and developing countries ODA is inevitable. He suggested that benefit from home assets and abroad capital is beneficial for ongoing economic growth, some specific measure is essential for effective economic growth and development. Whereas Dawson and Tiffin (1999) prescribed that in India, There have no long run association with official development assistance and per capita gross domestic product, analyzing the yearly data for 1961-92. They also recommended that foreign assistance had no effective power to economic growth in India. Another neighboring country case can be considered for this study is Pakistan. Jehangir and Ali (2019)had tried to find out the influence of ODA on Pakistan's economic development by estimating the time series variable data from 1991 to 1917. After analyzing the ADF and ARDL econometric methods they wanted to reveal short and long-run affinity of the ODA and per capita GDP. Their findings were negative in relation for both in the long run and short run between ODA and GDP per capita. In the same way inflation have negative influence in both long run and short run for economic growth.

The term foreign financial help or official development assistance (ODA) is broadly accepted and received as capital inflow from developed countries to less developing and under developed 


\section{International Journal of Social Science and Economic Research}

ISSN: $2455-8834$

Volume:05, Issue:10 "October 2020"

countries to be developed. The aim is to using yearly time series data from the period of 1980 to 2012 as a sample of Iran to measures the nexus between foreign aid and GDP per capita growth. The results showed that the influence of aid on economic growth is statistically efficient and significant with positive increment in nature. In conclusion ODA were more influential than other resources and assets inflows. (Refaei and Sameti, 2015).

An interesting work that can be related with the our study conducted by Ugwuanyi et al. (2017) was about the impact of external aid on poverty alleviation in Nigeria analyzing time series data from 1981 to 2014. Long-run and short-run dynamics were calculated by analyzing ARDL and ECM methods serially. Where the bound test measure the long run cointegration between the concerned variables. Findings said that official aid and poverty have long run relationship. They identified the strong evidence of convergence with a significant speed of adjustment in long-run.

Waqas Javaid (2017) investigated the influence of foreign capital inflows on GDP growth of Pakistan in the period of 1973-2014.ARDL and ECM result denoted that ODA and FDI have positive and significant stimulation on economic growth in both short run and long run. Beside this, remittance have no power to change economic condition. Benmamoun and Lehnert (2013) evidenced that in low income countries FDI, remittances, and official development assistance are positively related with the economic growth rate.

Sahoo and Sethi (2017) suggested that in the long run internal investment had a positive and significant influence on economic growth, at the same time ODA, FDI and GDP have faced a statistically significant negative impact on economic development by estimating the Johansen cointegration test and the vector vector-error correction model (VECM) methods. In long run it might be noted that external capital along with economic growth led to vary a positive change on economic advancement in India. Sethi et al. (2019) have studied and used different econometric time series techniques such as Johansen-Juselius test, VAR modelling and Granger causality test to determine the short-run and long-run association among the variables. The findings ensured that long-run relationship contains among foreign aid inflows, domestic investment, economic growth, inflation, and financial progress in India. Beside this, foreign aid does not effect on growth in both long-run and short-run perspective in Sri Lanka. Causal relationships are found in this empirical study.

The study calculated the impact of Foreign Capital Inflow (FCI) on the growth of Pakistan. Cointegration technique and Autoregressive Distributed Lag (ARDL) method have been applied for this purpose. The result said that in the long run as well as short run, foreign direct investment stimulates economic growth positively and only in the long run official development assistance with aid has positive influence on economic growth. So the policy prescription for 


\section{International Journal of Social Science and Economic Research}

ISSN: $2455-8834$

Volume:05, Issue:10 "October 2020"

Pakistan should be concerned on the official development assistance and foreign aid in the long run for economic growth and development. (Hye et al., 2010).

Gounder (2001) analyzed the effects of inflow aid on economic growth of Fiji. The result depicted that foreign aid expanded economic development.

The main observation of the study is assessing the causal relationship between ODA and economic growth in Vietnam. Panel data had been using on ODA and GDP from 63 provinces for Granger Causality test. The findings showed that there have causal effects between ODA and economic growth (GDP).ODA is essential for economic growth in provinces of Vietnam. (Duc and Lan, 2019).

Mahmood and Ellahi (2012)tried to get the relatedness between ODA and GDP. The work using annual time series data from 1970 to 2010. Econometric methods like ADF, ARDL were applied for the estimation. By the way the analytical result indicated that inflow of foreign capital had a strong and direct link with economic performance indicators. Analysis revealed neutrality on economic growth with ODA (Kalu and N., 2012).

\section{Data and Methodology}

To assess the link of the official development assistance (ODA) and gross domestic product (GDP) in Bangladesh, the data has been collected from World Development Indicators database. Time series data with annual in nature has been used from the period of 1971 to 2018 for both ODA and GDP variables. Here the ODA variable is taken from the net official development assistance received in current U.S. dollar. Besides ODA, time series data on GDP are also used in current U.S. dollar. For the convenience of analysis, both variables are expressed in natural logarithm. Variables description is given below.

Table 1: Variable description

\begin{tabular}{|l|l|}
\hline Variables & Description \\
\hline LNGDP & Natural log of GDP \\
\hline LNODA & Natural log of ODA \\
\hline
\end{tabular}

In time series econometric analysis, first essential thing is to check whether the data series is stationary or non-stationary. We used unit root test for this purpose. If the data series is nonstationary, it means there have unit root problem in data series. That implied the estimated mean and variance of the data series are not constant over time. It is essential for a data series to be stationary otherwise it might lead to spurious regression problem. Here we applied Augmented Dickey-Fuller (1979) test to identify the stationarity or order of integration for the further analysis. Then we tried to detect the long-run relationship between the two variables and perform 
ARDL bound test. Then we approaches to Granger causality test to find whether ODA caused GDP or GDP caused ODA. Some mandatory diagnostic test for the robustness of the model is implemented at the end.

\section{Testing for unit root test: The ADF test}

The ADF test was assumed that the error term ut is uncorrelated. The test was carried by adding the previous values of the dependent variable $\Delta Y t-i$ as explanatory variables. The three aspects of ADF test are expressed below.

No constant and no trend

$$
\Delta Y_{t}=\gamma_{1} Y_{t-1}+\sum_{i=1}^{m} \alpha i \Delta Y_{t-i}+\mu t
$$

Constant and no trend

$$
\Delta Y_{t}=\gamma^{0}+\gamma_{1} Y_{t-1}+\sum_{i=1}^{m} \alpha i \Delta Y_{t-i}+\mu t
$$

Constant and trend

$$
\Delta Y_{t}=\gamma^{0}+\gamma_{1} t+\delta_{2} Y_{t-1}+\sum_{i=1}^{m} \alpha i \Delta Y_{t-i}+\mu t
$$

Where, $\mu_{\mathrm{t}}$ is a pure white noise error term. To use the above model, we need to identify the pattern of the time series data by examining its graphical representation. If in data series there is no drift and trend we have to apply eq. (1); if in data series there is drift but no trend, we need to apply eq. (2); finally if data series have both drift and trend, we ought to apply Eq. (3) (Harris 1992).

\section{ARDL bound test for Cointegration Analysis}

Among the different cointegration techniques like Johansen (1988), Engel and Granger (1987), ARDL bound test and Johansen and Juselius (1990) we use ARDL bound test for cointegration analysis because of the data series having the characteristics of mixture of integration-that is $\mathrm{I}(0)$ and I(1). ARDL technique is not appropriate for the data of I (2) order of integration. ARDL techniques had been formatted to estimate the short run and long run level relationship among the regressand and regressors. For our analysis we specified the following models to clarify the long run relationships among the variables ODA and GDP.

$$
\begin{aligned}
\Delta L N G D P 0= & a_{1}+\alpha_{p} L N G D P_{t-1}+\alpha_{3} L N O D A_{t-1} \\
& +\sum_{i=1}^{q} \beta_{1} \Delta L N G D P_{t-i}+\sum_{i=1}^{q} \beta_{1} \Delta L N O D A_{t-i}+U_{i}
\end{aligned}
$$


International Journal of Social Science and Economic Research

ISSN: $2455-8834$

Volume:05, Issue:10 "October 2020"

$$
\begin{aligned}
\Delta L N O D A_{t}= & \alpha_{1}+\alpha_{p} L N O D A_{t-1}+\alpha_{3} L N G D P_{t-1} \\
& +\sum_{i=1}^{q} \beta_{1} \Delta L N O D A_{t-i}+\sum_{i=1}^{p} \beta_{1} \Delta L N G D P_{t-i}+U_{i}
\end{aligned}
$$

Firstly for the significant level relationship of the coefficient we consider the F-test in the ARDL model of cointegration analysis. (Pesaran et al., 2001). Then for the lagged variables we used Ttest because of identifying the long run level relationships.

Peseran et al. (2001) proposed two set of purely I(0) and purely I(1) critical values for regressors. The null hypothesis is"no long run relationship existed" will be rejected if the F-test statistic value is larger than the I(1) critical values at a particular significant level. As like the absolute value of T-test statistic in ARDL bound test must be larger than the absolute upper critical value, then we said that the assumption of null hypothesis that no long run relationship will be rejected. It means that there have long run relationships among the considered variables. At the same way we accept the null hypothesis of "no long run relationships" if the F-test statistic is less than the lower critical value and if the absolute value of T-test statistic is less than the absolute lower critical value. It indicates that there have no possibilities of long run equilibrium. And lastly if the value of test statistic lies in between the two lower and upper critical values, it implied inconclusive in aspect of long run relationship in the variables.

IF the F-statistic value is large enough to reject the assumption of null hypothesis and since we didn't included a constant or trend in the cointegration relationship, we can use the t-test critical values to determine the relationship. If the absolute value of the t-statistic is less than the absolute value of upper and lower bound of critical value. By rules we fail to reject the t-bound test of null hypothesis no long run relationship and conclude that there exists a cointegration relationship which is nonsensical.

\section{OLS short-run and long-run model}

After the ARDL bound test we need to take the decision of whether we ran ARDL short run model or estimate ECM model. If above any equation (4) and (5) have no evidence of cointegration, we just need to estimate short run model to obtain the Ordinary least square estimation and the equation is identified below.

$$
\begin{aligned}
& \Delta L N G D P_{t}=a_{t}+\sum_{i=1}^{p} \beta_{1} \Delta L N G D P_{t i}+\sum_{i=1}^{q} \beta_{2} \Delta L N O D A_{t i}+\boldsymbol{e}_{t t} \\
& \Delta L N O D A_{t}=a_{t}+\sum_{i=1}^{p} \beta_{1} \Delta L O D A_{t-i}+\sum_{i=1}^{q} \beta_{2} \Delta L N G D P_{t i}+\boldsymbol{e}_{2 t}
\end{aligned}
$$




\section{International Journal of Social Science and Economic Research}

ISSN: $2455-8834$

Volume:05, Issue:10 "October 2020"

If we find any sign of cointegration in the above any equation (4) and (5) we will estimate Error Correction Model. Before estimating the ECM we need to obtain the residual and the long run equation are identified below from which we can extract residuals.

$$
\begin{aligned}
& L N O D A=\alpha_{1}+\beta_{11} L N O D A_{t-i}+\beta_{21} L N G D P_{t-i}+e_{3 t} \\
& L N G D P=\alpha_{1}+\beta_{11} L N G D P_{t-i}+\beta_{21} L N O D A_{t-i}+e_{4 t}
\end{aligned}
$$

\section{Error Correction Model}

Very fast the Error Correction Mechanism was proposed by Sargan and for the correction of disequilibrium Engle and Granger made this mechanism well known. It is the analysis of short run dynamics that reveal the short run result association with long run equilibrium.

$$
\Delta L N O D A_{t}=\alpha_{1}+\sum_{i=1}^{p} \beta_{{ }_{i}} \Delta L N O D A_{t-i}+\sum_{i=1}^{q} \beta_{2 i} \Delta L N G D P_{t-i}+\lambda E C M_{t-1}+U_{t}
$$

Where $U_{\mathrm{t}}$ is the white noise error term, $\beta \mathrm{s}$ are the short run dynamics and $\lambda$ is the corresponding parameter that measures the speed of adjustment for each period to equilibrium. The range of the value of the ECM parameter exists in between 0 to -1 . If the value of ECM parameter is 0 then it denotes no convergence and -1 indicates perfect convergence to equilibrium.

A set of diagnostic test is conducted for the robustness of the ARDL model. At first we employed the Breusch-Godfrey serial correlation LM test to determine serial correlation for the residuals. Then we applied ARCH technique of heteroscedasticity to identify whether heteroscedasticity is exists or not. Jarque-Bera test of normality is also implemented for normality of the residuals of the model. For model specification Ramsey RESET test is used here. And at the last we applied cumulative sum (CUSUM) and the CUSUM square test for checking whether the model is stable or not.

\section{Granger Causality Test}

Unlike the cointegration technique, Granger causality test determine the directional causal relationship between two variables such as unidirectional or bidirectional causality. To fix it we applied Granger Causality techniques (Granger, 1996). Granger causality have the power of prediction like when one variable granger cause the other, after some lag the second series may indicates the same causal relationship. That means prediction will be easier by using the past information. In our model of GDP and ODA variables, the following equation of Granger causality being used.

$$
L N G D P_{t}=a_{0}+\sum_{i=1}^{p} \alpha_{1_{i}} L N G D P_{t-i}+\sum_{i=1}^{q} \alpha_{2 i} L N O D A_{t-i}+e_{1 t}
$$


International Journal of Social Science and Economic Research

ISSN: 2455-8834

Volume:05, Issue:10 "October 2020"

$$
L N O D A_{t}=a_{0}+\sum_{i=1}^{p} \alpha_{1 i} L N O D A_{t-i}+\sum_{i=1}^{q} \alpha_{2 i} L N G D P_{t-i}+e_{2 t}
$$

Where $\alpha_{1 \mathrm{i}}$ to $\alpha_{1 \mathrm{p}}$ in equation (11) are the lagged coefficient of dependent variable and $\alpha_{2 \mathrm{i}}$ to $\alpha_{2} q$ are the lagged coefficients of independent variables and also same in equation (12).

\section{Empirical result analysis}

The empirical results are explained in this section. At first the descriptive statistic are depicted in the below table 2 .

Table 2: Descriptive statistics.

\begin{tabular}{|l|l|l|l|l|l|}
\hline Variables & Observation & Mean & Std. Dev. & Min & Max \\
\hline GDP & 48 & $6.37 \mathrm{E}+10$ & $6.59 \mathrm{E}+10$ & $6.29 \mathrm{E}+09$ & $2.74 \mathrm{E}+11$ \\
\hline ODA & 48 & $1.34 \mathrm{E}+09$ & $7.10 \mathrm{E}+08$ & 15360000 & $3.78 \mathrm{E}+09$ \\
\hline
\end{tabular}

In table 2 the columns show variables, number of observations, mean value, Standard deviation, minimum value and maximum values of the corresponding time series.

\section{Results of unit root test}

The Augmented Dickey-Fuller test was implemented to the time series variables to determine their nature of stationarity. A stationarity of time series was the prerequisite for further analysis of forecasting in the realm of time series analysis. A Stationary is a stochastic process where mean and variance are constant over time (Gujrati 2003). In our analysis we were estimated our considering GDP and ODA time series variables to find out the order of integration and the results of the ADF test are given below:

Table 3: Unit root test result.

\begin{tabular}{|c|c|c|c|c|c|}
\hline Variables & Test & T-value & \multicolumn{3}{|c|}{ Critical Value } \\
\hline Level & & & $1 \%$ & $5 \%$ & $10 \%$ \\
\hline LNGDP & ADF & 0.070913 & -3.577723 & -2.925169 & -2.600658 \\
\hline LNODA & ADF & -9.073821 & -3.577723 & -2.925169 & -2.600658 \\
\hline First Difference & & & & & \\
\hline LNGDP & ADF & -7.253446 & -3.581152 & -2.926622 & -2.601424 \\
\hline LNODA & ADF & -10.82097 & -3.581152 & -2.926622 & -2.601424 \\
\hline
\end{tabular}




\section{International Journal of Social Science and Economic Research}

ISSN: 2455-8834

Volume:05, Issue:10 "October 2020"

Table 3 shows that in the level form LNGDP is not stationary but LNODA is stationary based on ADF test. Besides, LNGDP is stationary at its first difference form. Well we have I(0) and I(1) order of integration series that is perfectly suitable for ARDL bounds test method.

\section{ARDL bounds test results for cointegration}

The ARDL bound test method will give us the result in which we could identify the long run relationships between the concerned variables. Table 4 shows the estimated ARDL result. Akaike Information Criteria was used to select the appropriate lag length.

Table 4: Details of the selected ARDL model.

\begin{tabular}{|c|c|c|c|c|c|}
\hline $\begin{array}{l}\text { Dependent } \\
\text { variables }\end{array}$ & Regressors & Coefficient & Standard Error & t-statistic & Prob. \\
\hline$\Delta$ LNGDP & $\begin{array}{l}\text { LNGDP(-1) } \\
\text { LNGDP(-2) } \\
\text { LNGDP(-3) } \\
\text { LNGDP(-4) } \\
\text { LNODA } \\
\text { LNODA(-1) } \\
\text { LNODA(-2) } \\
\text { LNODA(-3) } \\
\text { LNODA(-4) } \\
\text { C }\end{array}$ & $\begin{array}{l}0.749850 \\
-0.216477 \\
0.114620 \\
0.370613 \\
0.191227 \\
-0.129022 \\
0.049295 \\
0.118024 \\
-0.129450 \\
-1.050067\end{array}$ & $\begin{array}{l}0.142480 \\
0.189228 \\
0.173532 \\
0.117331 \\
0.066864 \\
0.083552 \\
0.089218 \\
0.081706 \\
0.036313 \\
0.397781\end{array}$ & $\begin{array}{l}5.262846 \\
-1.143999 \\
0.660515 \\
3.158708 \\
2.859947 \\
-1.544225 \\
0.552521 \\
1.444494 \\
-3.564860 \\
-2.639810\end{array}$ & $\begin{array}{l}0.0000^{*} \\
0.2606 \\
0.5134 \\
0.0033^{*} \\
0.0072 * \\
0.1318 \\
0.5842 \\
0.1578 \\
0.0011 * \\
0.0124 * *\end{array}$ \\
\hline \multicolumn{2}{|c|}{$\begin{array}{l}\text { R-squared } 0.991204 \\
\text { Adjusted R-squared } 0.988875\end{array}$} & \multicolumn{2}{|c|}{ F-statistic 425.6989} & Durbin-Watson stat 1.695999 & 000000 \\
\hline $\begin{array}{l}\text { Dependent } \\
\text { variables }\end{array}$ & Regressors & Coefficient & Standard Error & t-statistic & Prob. \\
\hline$\triangle \mathrm{LNODA}$ & $\begin{array}{l}\text { LNODA(-1) } \\
\text { LNODA(-2) } \\
\text { LNGDP } \\
\text { LNGDP(-1) }\end{array}$ & $\begin{array}{l}0.581220 \\
0.063375 \\
0.820726 \\
-0.723731\end{array}$ & $\begin{array}{l}0.132341 \\
0.070861 \\
0.211696 \\
0.222755\end{array}$ & $\begin{array}{l}4.391847 \\
0.894364 \\
3.87691 \\
-3.248995\end{array}$ & $\begin{array}{l}0.0001 * \\
0.3763 \\
0.0004 * \\
0.0023 *\end{array}$ \\
\hline
\end{tabular}


International Journal of Social Science and Economic Research

ISSN: 2455-8834

Volume:05, Issue:10 "October 2020"

\begin{tabular}{|c|c|c|c|c|}
\hline $\mathrm{C}$ & 2.195647 & 0.631287 & 3.478051 & $0.0012 *$ \\
\hline \multicolumn{5}{|l|}{$\begin{array}{l}\text { R-squared } 0.795810 \\
\text { statistic) } 0.000000\end{array}$} \\
\hline Adjusted R-squared 0.775889 & \multicolumn{3}{|c|}{ Durbin-Watson stat2.103352 } & \\
\hline
\end{tabular}

$*, * *, * * *$ represents significance at $1 \%, 5 \%$ and $10 \%$ level respectively.

Table 4 includes all the details of the two equation of ARDL model that is selected ARDL $(4,4)$ and ARDL $(2,1)$ for this analysis. The adjusted R-squared, F-statistic and Durbin Watson stat affirm the appropriateness of the model.

In the table 5 we can see the result of long run relationship between the variables. Here the probability of the independent variable LNODA is above the 5\% so we will say that there is no long run relationship between LNGDP and LNODA when the dependent variable is LNGDP. Whereas the probability of the independent variable is below 5\% indicates that there is a long run relationship between LNODA and LNGDP when the dependent variable is LNODA. The Coefficient LNGDP is 0.272913 which mean that if LNGDP increased by $1 \%$ LNODA will be increased by $0.27 \%$ in the long run.

Table 5 ARDL model estimation results (Long Run).

\begin{tabular}{|l|l|l|l|l|l|}
\hline $\begin{array}{l}\text { Dependent } \\
\text { variables }\end{array}$ & $\begin{array}{l}\text { Independent } \\
\text { Variables }\end{array}$ & Coefficient & $\begin{array}{l}\text { Standard } \\
\text { Error }\end{array}$ & t-statistic & Prob. \\
\hline$\Delta$ LNGDP & LNODA & -5.378632 & 10.01578 & 0.537016 & 0.5948 \\
\hline$\Delta$ LNODA & LNGDP & 0.272913 & 0.103217 & 2.644061 & $0.0116^{* *}$ \\
\hline
\end{tabular}

$*, * *, * * *$ represents significance at $1 \%, 5 \%$ and $10 \%$ level respectively.

Table 6 is the result for long run bounds test that will help us to take decision of cointegration. Here F-test and T-test portrays the scenario of cointegration. When the dependent variable is $\triangle \mathrm{LNGDP}$, the value of F-statistic is less than all 1\%, 2.5\% and 5\% of the upper bound critical value and the absolute value of T-statistic is also less than the upper 1\%, 2.5\% and 5\% critical value. The results imply that there has no cointegration or no level relationships. The value of Fstatistic is larger than all the $1 \%, 2.5 \%$ and $5 \%$ of the upper bound critical value of the bound test in $\triangle$ LNODA equation. We have also mentioned the T-statistic where the absolute value also larger than all the $1 \%, 2.5 \%$ and $5 \%$ of the upper bound critical value of this equation. Therefore, the result indicates a long run relationship exist in the equation. 
International Journal of Social Science and Economic Research

ISSN: 2455-8834

Volume:05, Issue:10 "October 2020"

Table 6: ARDL bound test result with F-statistic and T-statistic.

\begin{tabular}{|c|c|c|c|}
\hline Dependent Variable & \multirow[t]{2}{*}{ Critical value } & \multicolumn{2}{|c|}{ F-Statistic $\quad 5.074151$} \\
\hline \multirow[t]{9}{*}{$\Delta \mathrm{LNGDP}$} & & $\mathrm{I}(0)$ & $\mathrm{I}(1)$ \\
\hline & $95 \%$ & 4.94 & 5.73 \\
\hline & $97.5 \%$ & 5.77 & 6.68 \\
\hline & $99 \%$ & 6.84 & 7.84 \\
\hline & Critical Value & \multicolumn{2}{|c|}{ t-statistic 0.719236} \\
\hline & & $\mathrm{I}(0)$ & $\mathrm{I}(1)$ \\
\hline & $95 \%$ & -2.86 & -3.22 \\
\hline & $97.5 \%$ & -3.13 & -3.5 \\
\hline & $99 \%$ & -3.43 & -3.82 \\
\hline Dependent Variable & \multirow{2}{*}{ Critical value } & \multicolumn{2}{|c|}{$\begin{array}{ll}\text { F-Statistic } & 6.919412\end{array}$} \\
\hline \multirow[t]{9}{*}{$\triangle \mathrm{LNODA}$} & & $\mathrm{I}(0)$ & $\mathrm{I}(1)$ \\
\hline & $95 \%$ & 4.94 & 5.73 \\
\hline & $97.5 \%$ & 5.77 & 6.68 \\
\hline & $99 \%$ & 6.84 & 7.84 \\
\hline & \multirow[t]{2}{*}{ Critical Value } & $\begin{array}{c}\text { t-statistic - } \\
3.569773\end{array}$ & \\
\hline & & $\mathrm{I}(0)$ & $\mathrm{I}(1)$ \\
\hline & $95 \%$ & -2.86 & -3.22 \\
\hline & $97.5 \%$ & -3.13 & -3.5 \\
\hline & $99 \%$ & -3.43 & -3.82 \\
\hline
\end{tabular}

\subsection{Short Run and Long run OLS Model Result}

The OLS model is a method of explaining the dependent variable associated with one or more independent variable using regression analysis. The OLS model have some assumptions (called 


\section{International Journal of Social Science and Economic Research}

ISSN: $2455-8834$

Volume:05, Issue:10 "October 2020"

Gauss-Markov assumptions) for better result and efficient estimation. These assumptions affirm the accuracy of the estimation results.

In the table 7 the OLS estimation results depicted. In the short run model the value of the coefficient of lag 2 of LNGDP indicates that $1 \%$ increase in $\mathrm{D}(\operatorname{LNGDP}(-2))$ lead to $0.37 \%$ decrease in LNGDP and is statistically significant at $1 \%$ level. The coefficient value of lag 4 of LNGDP is -0.156817 meaning that $1 \%$ increase in $\mathrm{D}(\operatorname{LNGDP}(-4))$ decreases LNGDP at $0.16 \%$ and the coefficient value lag 5 of LNODA is 0.054933 indicates a $1 \%$ increase in D(LNODA(5)) makes $0.054 \%$ increase in LNGDP and both of this are also significant at $10 \%$ level. The Rsquared value is 0.484704 and adjusted R-Squared value is 0.318479 indicate the goodness of fit measure of the regression model. The Durbin-Watson stat value is 1.777745 and the rule of thumbs indicate a positive autocorrelation in the short run model.

In the long run OLS model the dependent variable is LNODA and independent variable is LNGDP where the value of the coefficient of 1 lag of LNODA implies that $1 \%$ increase in LNODA(-1) lead to increase $0.39 \%$ of LNODA and is statistically significant at $1 \%$ level. The value of the coefficient of $\operatorname{LNGDP}(-1)$ implies that $1 \%$ increase in $\operatorname{LNGDP}(-1)$ lead to $0.18 \%$ increase in LNODA and it is also significant at $1 \%$ level. The R-squared value is 0.767946 and adjusted R-Squared value is 0.757398 indicate the goodness of fit measure of the regression model. The Durbin-Watson stat value is 1.734944 and the rule of thumbs indicate a positive autocorrelation in this model.

Table 7: Short Run and Long run OLS Model Result.

\begin{tabular}{|c|c|c|c|c|c|}
\hline \multicolumn{6}{|c|}{ Short run OLS Model Result } \\
\hline $\begin{array}{l}\text { Dependent } \\
\text { variables }\end{array}$ & Regressors & Coefficient & Standard Error & t-statistic & Prob. \\
\hline$\Delta$ LNGDP & $\begin{array}{l}\text { C } \\
\text { D(LNGDP(-1)) } \\
\text { D(LNGDP(-2)) } \\
\text { D(LNGDP(-3)) } \\
\text { D(LNGDP(-4)) } \\
\text { D(LNGDP(-5)) } \\
\text { D(LNODA }(-1)) \\
\text { D(LNODA }(-2)) \\
\text { D(LNODA }(-3)) \\
\text { D(LNODA }(-4)) \\
\text { D(LNODA }(-5))\end{array}$ & $\begin{array}{l}0.043392 \\
0.198053 \\
-0.371586 \\
-0.064167 \\
-0.156817 \\
-0.074411 \\
0.052821 \\
0.043255 \\
0.071108 \\
0.022415 \\
0.054933\end{array}$ & $\begin{array}{l}0.010492 \\
0.137961 \\
0.101474 \\
0.108099 \\
0.088440 \\
0.083084 \\
0.049842 \\
0.049523 \\
0.049303 \\
0.045812 \\
0.032243\end{array}$ & $\begin{array}{l}4.135776 \\
1.435578 \\
-3.661901 \\
-0.593598 \\
-1.773148 \\
-0.895615 \\
1.059760 \\
0.873427 \\
1.442255 \\
0.489295 \\
1.703747\end{array}$ & $\begin{array}{l}0.0003 * \\
0.1611 \\
0.0009 * \\
0.5571 \\
0.0860 * * * \\
0.3774 \\
0.2974\end{array}$ \\
\hline
\end{tabular}


International Journal of Social Science and Economic Research

ISSN: 2455-8834

Volume:05, Issue:10 "October 2020"

\begin{tabular}{|c|c|c|c|c|c|}
\hline & & & & & $\begin{array}{l}0.3891 \\
0.1593 \\
0.6281 \\
0.0984 * * *\end{array}$ \\
\hline \multicolumn{6}{|c|}{$\begin{array}{l}\text { R-squared } 0.484704 \\
\text { Adjusted R-Squared0.318479 }\end{array}$} \\
\hline \multicolumn{6}{|c|}{ Long run OLS Model Result } \\
\hline $\begin{array}{l}\text { Dependent } \\
\text { variables }\end{array}$ & Regressors & Coefficient & Standard Error & t-statistic & Prob. \\
\hline$\Delta$ LNODA & $\begin{array}{l}\text { C } \\
\text { LNODA(-1) } \\
\text { LNGDP(-1) }\end{array}$ & $\begin{array}{l}3.588043 \\
0.391182 \\
0.185248\end{array}$ & $\begin{array}{l}0.459691 \\
0.059203 \\
0.050374\end{array}$ & $\begin{array}{l}7.805332 \\
6.607469 \\
3.677480\end{array}$ & $\begin{array}{l}0.0000^{*} \\
0.0000^{*} \\
0.0006 *\end{array}$ \\
\hline
\end{tabular}

R-squared $0.767946 \quad$ F-statistic72.80557 $\quad$ Prob(F-statistic) 0.000000

Adjusted R-Squared $\quad$ 0.757398Durbin-Watson stat 1.734944

$*, * *, * * *$ represents significance at $1 \%, 5 \%$ and $10 \%$ level respectively.

\section{Result of Error Correction Model}

The estimated result of Error Correction Model is given below. In short run dynamics of value and sign of the coefficient of lagged dependent variable is significant and the value of the coefficient of ECM with desirable negative sign indicates an adjustment toward long run relationship if a shock is experienced in the short run. The speed of adjustment from short run to long run equilibrium is equal to value of the coefficient ECM is -0.655 that is $65 \%$ of disequilibrium will be corrected from short run to long run per year.

Table 8: Short run ECM result. 
International Journal of Social Science and Economic Research

ISSN: 2455-8834

Volume:05, Issue:10 "October 2020"

\begin{tabular}{|l|l|l|c|c|l|}
\hline $\begin{array}{l}\text { Dependent } \\
\text { variable }\end{array}$ & Regressors & Coefficient & Standard Error & t-statistic & Prob. \\
\hline D(LNODA) & C & 0.015478 & 0.018273 & 0.847009 & 0.4018 \\
& D(LNODA(-1)) & 0.234154 & 0.091913 & 2.547551 & $0.0146^{* *}$ \\
& D(LNGDP(-1)) & -0.111980 & 0.237127 & -0.472237 & 0.6392 \\
& ECM(-1) & -0.655591 & 0.186459 & -3.516011 & $0.0011^{*}$ \\
& & & & & \\
\hline
\end{tabular}

$*, * *, * * *$ represents significance at $1 \%, 5 \%$ and $10 \%$ level respectively.

\section{Diagnostic Test}

Table 9 shows a set of diagnostic test for the vigorousness of the model. For serial correlation we applied Breusch-Godfrey serial correlation LM test and for heteroscedasticity ARCH test is applied. The estimated result indicates that the obtained residuals were homoscedastic and the model was not suffering from serial correlation. For the normality assumption we considered the normality test of Jarque- Bera and its results said that the residuals were normally distributed. Another important diagnostic for appropriate functional form of the model is Ramsey RESET test and the estimated indicated that the model is well specified or free from specification error.

Table 9: Results of different diagnostic test.

\begin{tabular}{|c|c|c|c|c|}
\hline Dependent variable & \multicolumn{4}{|c|}{ Breusch-Godfrey serial correlation LM } \\
\hline$\Delta \operatorname{lngdp}$ & $\begin{array}{l}\text { F-statistic } \\
\text { Obs*R-squared }\end{array}$ & $\begin{array}{l}0.758246 \\
5.344918\end{array}$ & $\begin{array}{l}\text { Prob. } \\
0.5879 \\
\text { Prob. } \\
0.3753\end{array}$ & $\begin{array}{r}\mathrm{F}(5.26) \\
\text { Chi-square(5) }\end{array}$ \\
\hline$\Delta \operatorname{lnoda}$ & $\begin{array}{l}\text { F-statistic } \\
\text { Obs*R-squared }\end{array}$ & $\begin{array}{l}1.600729 \\
1.728457\end{array}$ & $\begin{array}{l}\text { Prob. } \\
0.2129 \\
\text { Prob. } \\
0.1886\end{array}$ & $\begin{array}{r}\mathrm{F}(1.41) \\
\text { Chi-square(1) }\end{array}$ \\
\hline Dependent variable & Heteroscedastici & $\mathrm{ARCH}$ & & \\
\hline$\Delta \operatorname{lngdp}$ & $\begin{array}{l}\text { F-statistic } \\
\text { Obs*R-squared }\end{array}$ & $\begin{array}{l}0.623546 \\
0.645206\end{array}$ & $\begin{array}{l}\text { Prob. } \\
0.4345 \\
\text { Prob. } \\
0.4218\end{array}$ & $\begin{array}{r}\mathrm{F}(1.39) \\
\text { Chi-square (1) }\end{array}$ \\
\hline
\end{tabular}


International Journal of Social Science and Economic Research

ISSN: 2455-8834

Volume:05, Issue:10 "October 2020"

\begin{tabular}{|c|c|c|}
\hline$\Delta$ lnoda & $\begin{array}{l}\text { F-statistic } \\
1.125436 \\
\text { Obs*R-squared } \\
1.147742\end{array}$ & $\begin{array}{lr}\text { Prob. } & \mathrm{F}(1.43) \\
0.2947 & \\
\text { Prob. } & \text { Chi-square(1) } \\
0.2840 & \end{array}$ \\
\hline Dependent variable & Normality Distribution test Jarque- & Bera \\
\hline$\Delta \operatorname{lngdp}$ & $\begin{array}{l}\text { Jarque-Bera } \\
1.790325\end{array}$ & $\begin{array}{l}\text { Probability } \\
0.408541\end{array}$ \\
\hline$\Delta$ lnoda & $\begin{array}{l}\text { Jarque-Bera } \\
1.838866\end{array}$ & $\begin{array}{l}\text { Probability } \\
0.398745\end{array}$ \\
\hline Dependent variable & Ramsey RESET Test & \\
\hline$\Delta \operatorname{lngdp}$ & $\begin{array}{lr}\text { t-statistic } & \\
1.121950 & \\
\text { F-statistic } & 1.258772 \\
\text { Likelihood } & \text { ratio } \\
1.726312 & \end{array}$ & $\begin{array}{l}\text { Probability } \\
0.2708 \\
\text { Probability } \\
0.2708 \\
\text { Probability } \\
0.1889\end{array}$ \\
\hline$\Delta \operatorname{lnoda}$ & $\begin{array}{ll}\text { t-statistic } & \\
0.520924 & \\
\text { F-statistic } & \\
0.271362 & \\
\text { Likelihood } & \\
0.303451 & \text { ratio }\end{array}$ & $\begin{array}{l}\text { Probability } \\
0.6052 \\
\\
\text { Probability } \\
0.6052 \\
\text { Probability } \\
0.5817\end{array}$ \\
\hline
\end{tabular}

\section{Stability Test}

R. L. Brown, J. Durbin and J. M. Evans (1975) developed a testing procedure of recursive residual test of cumulative sum and cumulative sum square for the stability of the parameter in the model. The CUSUM and CUSUM square test states that the model would be stable if the plot of CUSUM and CUSUM square exist in between 5\% significant level. In figure 2 the plot of the dependent variable GDP indicates a parameter consistency and a well stable model this is. 
International Journal of Social Science and Economic Research

ISSN: 2455-8834

Volume:05, Issue:10 "October 2020"

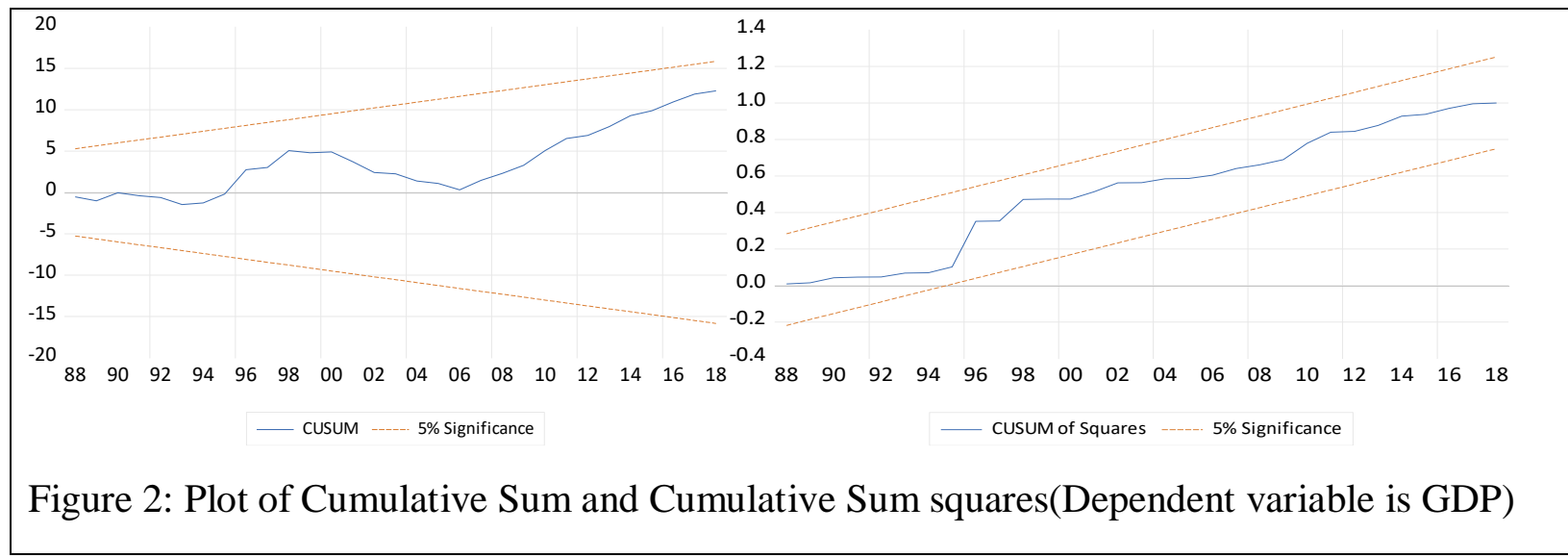

In figure 3 we have seen that the plot of CUSUM is not within the 5\% significant level bound but CUSUM square remained between 5\% significant bound. This result portrayed that there is a structural break in the short run because after 1990s Bangladesh economy experienced a change in political power of Army ruling government. Besides this the CUSUM square plot lies in between the $5 \%$ critical bound and indicate no structural change in the long run.

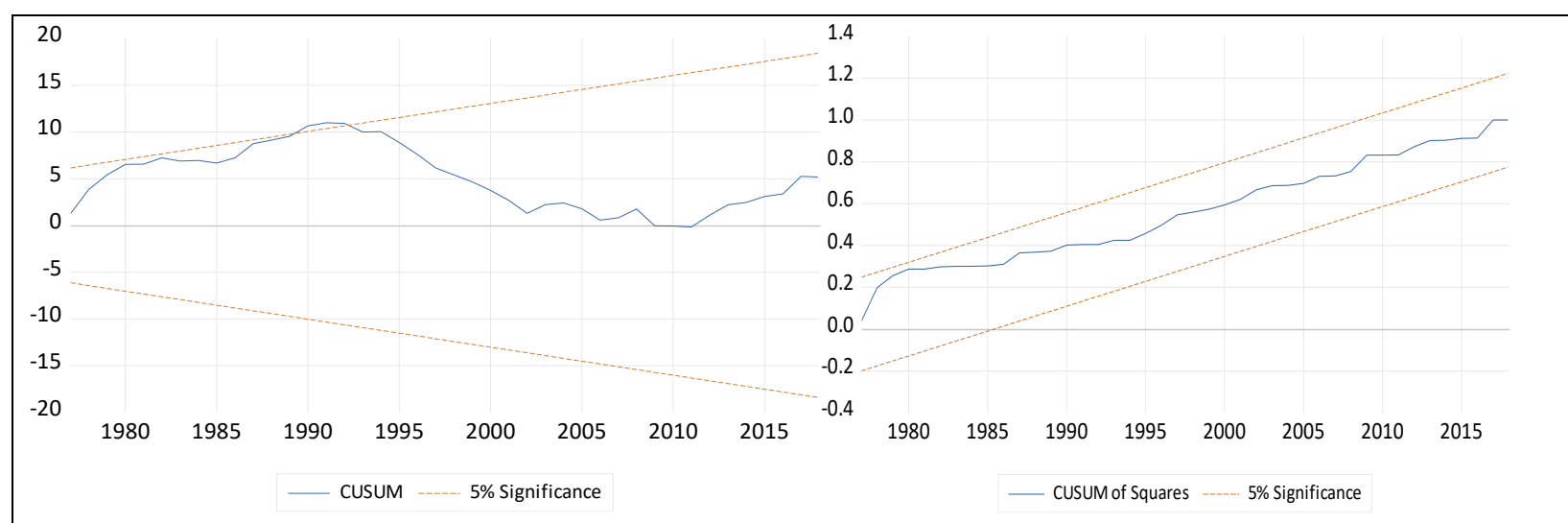

Figure 3: Plot of Cumulative Sum and Cumulative Sum squares(Dependent variable is ODA)

\section{Results of Granger Causality test}

The GDP and ODA time series were stationary and the residuals were serially uncorrelated. We proceed to apply Granger Causality test proposed by Granger (1969). In the short run OLS model, The Granger causality results of the model of dependent variable of LNGDP and independent variable of LNODA indicate a unidirectional causality run from LNODA to 
International Journal of Social Science and Economic Research

ISSN: 2455-8834

Volume:05, Issue:10 "October 2020"

LNGDP because we reject the null hypothesis of "LNODA does not Granger Cause LNGDP" as the $\mathrm{p}$ value of 0.0124 is lower than $5 \%$ significant level. It means LNODA Granger Cause LNGDP. In the long run OLS model, the findings of Granger causality lead to reject the null hypothesis that "LNGDP does not Granger Cause LNODA" at 5\% level of significance. Table 8 shows the result of probability value of the null hypothesis "LNGDP does not Granger Cause LNODA" is 0.0006 which is lower than 0.0500 . So in corollary we can say LNGDP granger cause LNODA. In corollary there have a unidirectional causality from GDP to ODA in Bangladesh. The findings might be supported the reality in the case of Bangladesh as Official Development Assistance influence economic growth.

Table 10: Results of Granger causality.

\begin{tabular}{|l|l|l|l|l|}
\hline \multicolumn{5}{|l|}{ Pairwise Granger Causality Tests (Dependent Variable: LNGDP) } \\
\hline Null Hypothesis & Obs & F-statistic & Prob. & Decision \\
\hline LNODA does not Granger Cause LNGDP & 43 & 3.49807 & $0.0124^{* *}$ & Rejected \\
\hline LNGDP does not Granger Cause LNODA & & 0.57979 & 0.7151 & Accepted \\
\hline Pairwise Granger Causality Tests (Dependent Variable: LNODA) & Decision \\
\hline Null Hypothesis & Obs & F-statistic & Prob. & Rejected \\
\hline LNGDP does not Granger Cause LNODA & 47 & 13.5239 & $0.0006^{*}$ & Accepted \\
\hline LNODA does not Granger Cause LNGDP & & 2.36685 & 0.1311 & \\
\hline
\end{tabular}

$*, * *, * * *$ represents significance at $1 \%, 5 \%$ and $10 \%$ level respectively.

\section{Conclusion and Policy Recommendation}

This is an empirical study conducted to assessing the nexus between ODA and GDP. At first the $\mathrm{ADF}$ test is used for the stationarity of the time series data of corresponding variables. The nature of the considering time series data dictated to apply ARDL bound testing method for checking whether the cointegration exists or not. If there is no cointegration between the concerned variables, we estimate an OLS short run model. The ARDL bound test result revealed the evidence of cointegration between the dependent variable LNODA and independent variable LNGDP that there exist long run relationship. Then we estimate long run OLS model to make residual series by which we can calculate ECM model. The coefficient of ECM in ODA equation had the desirable negative sign and even statistically significant at $1 \%$ level. The value of the 
International Journal of Social Science and Economic Research

ISSN: 2455-8834

Volume:05, Issue:10 "October 2020"

coefficient of ECM indicates the speed of adjustment of disequilibrium from short run to long run. The disequilibrium will be corrected within a year of $65 \%$ and converged to long run equilibrium. In short run OLS model the Granger casualty test is implemented and the findings is a unidirectional causal relationship between the variables ODA to GDP and in the long run OLS model the result also shows a unidirectional causality between the variables running from GDP to ODA.

However, the results of the study have some policy recommendation. As GDP causes ODA, in the long run the appropriate measurement of GDP may influence ODA in Bangladesh. So the efficient use of the resources, human capital could accelerate the wheel of economic growth therefore it may lead to change in ODA that can be helpful for the wellbeing of Bangladesh. Therefore, policymaker should consciously utilize the capital inflow of ODA for the wellbeing and betterment of living standard of the people of Bangladesh. Policy makers should ensure infrastructural development, maintaining the steady state growth and well international trade environment and political stability for external investment can be alluring for more capital inflow lead to a betterment of life.

\section{References}

A.A.G.Ali, C.Malwanda and Y. Suliman (1999). Official development assistance to Africa: An overview. Journal of African Economies. 8(4), 504-527. https://doi.org/10.1093/jae/8.4.504

Dr. Nguyen Hoang Tien (2019). Contribution of ODA to Vietnam's economy. International Journal of Foreign Trade and International Business. 1(1). 05-08.DOI:

10.13140/RG.2.2.25289.98409

Dang Ngoc Duc and Do Thi Ngoc Lan (2019). ODA and provincial economic growth in Vietnam. International Finance and Banking. 6(1). DOI: 10.5296/ifb.v6i1.14311

Daniel Sakyi (2011). Trade openness, foreign aid and economic growth in post-liberalization Ghana: An application of ARDL bounds test. Journal of Economics and International Finance. 3(3). 146-156. https://academicjournals.org/journal/JEIF/article-full-textpdf/2FDBA2E4696

D. O. Olayungbo and Ahmod Quadri (2019). Remittances, financial development and economic growth in sub-Saharan African countries: evidence from a PMG-ARDL approach. Financial Innovation. 5(9). DOI: 10.1186/s40854-019-0122-8 


\section{International Journal of Social Science and Economic Research}

ISSN: 2455-8834

Volume:05, Issue:10 "October 2020"

Dang Van Dan and Vu Duc Binh (2019). Evaluating the impact of official development assistance (ODA) on economic growth in developing countries. Springer Nature Switzerland AG. 809, 910-918. DOI: 10.1007/978-3-030-04200-4_66

Damoder N. Gujrati, Dawn C Porter, Sangeetha Gunasekar (2009). Basic Econometrics (5th Edition). McGraw-Hill publication. https://books.google.com.bd/books?hl=en\&lr=\&id=WcCjAgAAQBAJ\&oi=fnd\&pg=PR3 $\& d q=$ Damoder+N.+Gujrati,+Dawn+C+Porter,+Sangeetha+Gunasekar.+Basic+Economet rics,Fifth+Edition,+++++++++++McGraw

Hill+publication.\&ots=ebdvX4Q9LQ\&sig=RGw5uBMYXyU8orDLBUdPqGPQPiQ\&re dir_esc=y\#v=onepage \&q=Damoder\%20N.\%20Gujrati\%2C\%20Dawn\%20C\%20Porter\% 2C\%20Sangeetha\%20Gunasekar.\%20Basic\%20Econometrics\%2CFifth\%20Edition\%2C $\% 20 \% 20 \% 20 \% 20 \% 20 \% 20 \% 20 \% 20 \% 20 \% 20 \% 20$ McGraw-Hill\%20publication.\&f=false

Folega Zounogo Abdou-Razak, Zhang Lian Cheng and Abdou M. T. Watara (2019).

Relationship between official development assistance and economics growth: A VAR estimation. International Journal of Recent Scientific Research. 10(11) F, 36095-36099. DOI: http://dx.doi.org/10.24327/ijrsr.2019.1011.4236

Fambon, Samuel (2013). Foreign capital inflow and economic growth in Cameroon, WIDER Working Paper, No. 2013/124, The United Nations University World Institute for Development Economics Research (UNU-WIDER), Helsinki. https://www.wider.unu.edu/sites/default/files/WP2013-124.pdf

Granger C.W.J. (1969). Investing causal relations by econometrics models and Cross Spectral Methods. Econometrica, 37(3), 434-438. DOI: 10.2307/1912791

Geetilaxmi Mohapatra, A. K. Giri and Madhu Sehrawat (2016). Foreign aid, macroeconomic policies and economic growth nexus in India: An ARDL bounds testing approach. Theoretical and Applied Economics. XXIII .4(609), 183-202. http://store.ectap.ro/articole/1232.pdf

Hillary Chijindu Ezeaku, Anthony E. Ageme, C. A. Anisiuba and J. U. J. Onwumere (2018). Official development assistance and economic development: Evidence from the West African monetary zone. Asian Journal of Economics, Business and Accounting. 4(3). 1-8. DOI: $10.9734 / \mathrm{AJEBA} / 2017 / 36247$ 
International Journal of Social Science and Economic Research

ISSN: 2455-8834

Volume:05, Issue:10 "October 2020"

Hynes, W. and S. Scott (2013). The evolution of official development assistance: Achievements, criticisms and a way forward. OECD Development Co-operation Working Papers. No. 12, OECD Publishing. DOI: 10.1787/5k3v1dv3f024-en

Hafiz Zahid Mahmood and Nazima Ellahi (2012). Bounds testing approach to find the impact of capital inflow on real output growth of Pakistan. International Journal of Economics and Finance. 4(4). DOI: 10.5539/ijef.v4n4p106

Ifeoma Ifeyinwa Momah (2018). Official development assistance and the factors impeding its effectiveness in Africa. Africa Review. DOI: 10.1080/09744053.2018.1485252

I. Pokorna and L. Smutka (2009). The influence of official development assistance on economical development of the selected groups of developing countries around the world. Agris on-line Papers in Economics and Informatics. 1(1).1-20. Czech University of Life Sciences Prague, Faculty of Economics and Management,DOI:

10.22004/ag.econ.96848

Kazi Mezbah Uddin Ahamad, Noushin Farjana Huda Chowdhury and Moniruzzaman Muzib (2019). Aid-growth nexus in Bangladesh: An evidence from the ARDL bound testing approach. Journal of Economics and Sustainable Development. 10(6). DOI: 10.7176/JESD/10-6-17

Kalu, Kalu N. (2012). Liberal economics, governance, and official development assistance: Empirical comments on theoretical themes. African Social Science Review. 5(1). https://digitalcommons.kennesaw.edu/assr/vol5/iss1/4?utm_source=digitalcommons.kenn esaw.edu\%2Fassr\%2Fvo15\%2Fiss1\%2F4\&utm_medium=PDF\&utm_campaign=PDFCov erPages

Kalpana Sahoo and Narayan Sethi (2017). Impact of foreign capital on economic development in India: An econometric investigation. Global Business Review. 18(3). 1-15. https://doi.org/10.1177/0972150917692198

Mamoun Benmamoun and Kevin Lehnert (2013). Financing growth: Comparing the effect of FDI, ODA and international remittance. Journal of Economic Development. 38(2). DOI: 10.35866/caujed.2013.38.2.002 
International Journal of Social Science and Economic Research

ISSN: $2455-8834$

Volume:05, Issue:10 "October 2020"

Muhammad Tariq, Muhammad Jehangir and Hussain Ali (2019). An investigation of the effects of the official development assistance on GDP per capita in Pakistan. Global Social Sciences Review (GSSR). IV (1), 233-239. DOI: 10.31703/gssr.2019 (IV-I).31

Muhammad Abdul Wahab and Vaqar Ahmed (2011). Foreign assistance and economic growth evidence from Pakistan 1972-2010. World Economics. 12(4). https://mpra.ub.unimuenchen.de/30344/

Mohammed Elhaj Mustafa, Manal Mahagoub Elshakh and Ebaidalla Mahjoub Ebaidalla (2019).Does foreign aid promote economic growth in Sudan? Evidence from ARDL bounds testing analysis. Journal of Economic Cooperation and Development. 40(3). 115140. https://bit.ly/2UZLQ3F

Moga Tano Jilenga1, Helian Xu and Igor-Mathieu Gondje-Dacka (2016). The impact of external debt and foreign direct investment on economic growth: Empirical evidence from Tanzania. International Journal of Financial Research. 7(2). DOI: 10.5430/ijfr.v7n2p154

M. Hashem Pesaran,Yongcheol Shin and Richard J. Smith(2001). Bounds testing approaches to the analysis of level relationships. Journal of Applied Econometrics. 16(3), 289-326. DOI: $10.1002 /$ jae.616

Narayan Sethi, Padmaja Bhujabal, Aurolipsa Das and Sanhita Sucharita (2019). Foreign aid and growth nexus: Empirical evidence from India and Sri Lanka. Economic Analysis and Policy. 64. 1-12. DOI: 10.1016/j.eap.2019.07.002

Nigel Driffield and Chris Jones (2013). Impact of FDI, ODA and migrant remittances on economic growth in developing countries: A systems approach. European Journal of Development Research. 25, 173-196. DOI: 10.1057/ejdr.2013.1

Ognjen Eric (2017). Analysis of the effects of the EU official development assistance to the Western Balkans. ACTA Economica. XV (26). DOI: 10.7251/ACE1726123E

Prof Haile Girma (2015). The impact of foreign aid on economic growth: Empirical evidence on Ethiopia (1974-2011) using ARDL approach. Journal of Research in Economics and International Finance (JREIF). 4(1). 1-12. DOI:

http://dx.doi.org/10.14303/jrief.2014.044 
International Journal of Social Science and Economic Research

ISSN: 2455-8834

Volume:05, Issue:10 "October 2020"

P. J. Dawson and Richard Tiffin (1999). Is there a long-run relationship between ODA and GDP? The case of India. Applied Economics Letters, 6(5), 275-277. DOI:

$10.1080 / 135048599353212$

Qazi Muhammad Adnan Hye, Akmal, Muhammad Shahbaz and Hye, Amra(2010). Foreign capital inflow and economic growth nexus: A case study of Pakistan. The IUP Journal of Applied Economics. 1(9), 16-26. https://ssrn.com/abstract=1535737

Ramiar Refaei and Morteza Sameti (2015). Official development assistance and economic growth in Iran. International Journal of Management, Accounting and Economics. 2(2). https://www.academia.edu/27071389/Official_Development_Assistance_and_Economic_ Growth_in_iran

Robert Suphian and Sung-soo Kim (2016). Official development assistance and economic growth in East African countries. The Journal of Peace Studies.

http://hdl.handle.net/20.500.11810/4623

Rukmani Gounder (2001). Aid-growth nexus: empirical evidence from Fiji. Applied Economics, 33(8), 1009-1019. DOI: 10.1080/000368401300182789

R. L. Brown, J. Durbin and J. M. Evans (1975). Techniques for testing the constancy of regression relationships over time. Journal of the Royal Statistical Society. 37(2), 149192. DOI: $10.2307 / 2984889$

Sams Uddin Ahmed (2019). Budget deficit in bangladesh: Causes and remedies. The Cost and Management. 47(3). http://www.icmab.org.bd/wp-content/uploads/2019/12/4.BudgetDeficit.pdf

Ugwuanyi, Uche Boniface, Ezeaku, Hillary Chijindu and Imo G. Ibe (2017). The impact of official aid on poverty reduction: Empirical evidence from Nigeria (1981-2014) using the ARDL and bound test approach. European Journal of Sustainable Development. 6(2), 111-120. DOI: 10.14207/ejsd.2017.v6n2p111

Waqas Javaid (2017). Impact of foreign financial inflow on economic growth of Pakistan. Do remittances, foreign aid, and ODA behave similarly? Journal of Behavioural Economics, 
International Journal of Social Science and Economic Research

ISSN: 2455-8834

Volume:05, Issue:10 "October 2020"

Finance, Entrepreneurship, Accounting and Transport. 5(1), 10-18. DOI: 10.12691/jbe$5-1-2$

World Bank. (2020). World Development Indicator. Retrieved from https://data.worldbank.org/

Index Mundi. (2020). Retrieved from https://www.indexmundi.com/facts/bangladesh/net-odareceived

Wikipedia. (2020). Retrieved from https://en.wikipedia.org/wiki/Economy_of_Bangladesh

Investopedia. (2020). Retrieved from https://www.investopedia.com/terms/g/gdp.asp

CEIC Data. (2020). Bangladesh Nominal GDP. Retrieved from

https://www.ceicdata.com/en/indicator/bangladesh/nominal-gdp 